\title{
Study of Early Age Properties and Behaviour of Concrete with GGBS as Partial Replacement of Cement
}

\author{
Manjunatha $\mathbf{M}^{1^{*}}$ and Jeevan $\mathrm{H}^{2}$ \\ ${ }^{1}$ Department of Civil Engineering, NMAM Institute of Technology, Nitte, Karnataka, India \\ ${ }^{2}$ Department of Civil Engineering, National Institute of Engineering, Mysore, Karnataka, India
}

\begin{tabular}{|c|c|}
\hline \multirow{4}{*}{$\begin{array}{l}\text { ADStract } \\
\text { Ground granulated blast furnace slag (GGBS) is used as alternative binder material for } \\
\text { cement in the concrete. The use of GGBS in concrete production contributes to the saving of } \\
\text { natural resources and energy spent in cement manufacturing process and also to reduce } \\
\mathrm{CO}_{2} \text { emissions and environmental impact. In this research, GGBS is used as binder material } \\
\text { for Ordinary Portland Cement in concrete by replacing cement up to } 45 \% \text { by weight of } \\
\text { cementitious material. This investigation is carried out to study the fresh properties, early age } \\
\text { strength properties and mechanical properties such as compressive strength of concrete } \\
\text { specimen by partial replacement of cement with GGBS up to } 45 \% \text { and compared with } \\
\text { referral mix. A total of four concrete mix proportion (NC, Mix } 1-15 \% \text {, Mix } 2-30 \% \text {, Mix } 3-45 \% \text { ) } \\
\text { with and without GGBS were made. The compression test were carried out to determine the } \\
\text { strength properties of concrete at the age of } 3 \text { days, } 7 \text { days and } 28 \text { days. The test result } \\
\text { shows that the } 28 \text { days compressive strength at } 15 \% \text { GGBS content for M35 and M } 40 \text { grade } \\
\text { of concrete is comparable with referral mix. It is observed that concrete made with GGBS } \\
\text { have lower strength at early ages, but gain strength more steadily than equivalent concrete } \\
\text { made with Portland cement which is having higher early age strength but does not rise } \\
\text { rapidly on the later stages. The M M grade concrete has better workability when compared } \\
\text { with M35 grade concrete. } \\
\text { Coppright@2015 STAR Journal, Wollega University. All Rights Reserved. }\end{array}$} & Article Information \\
\hline & $\begin{array}{l}\text { Article History: } \\
\text { Received : } 06-10-2015 \\
\text { Revised : 18-12-2015 } \\
\text { Accepted : } 23-12-2015\end{array}$ \\
\hline & $\begin{array}{l}\text { Keywords: } \\
\text { Ground Granulated Blast } \\
\text { Furnace Slag }\end{array}$ \\
\hline & $\begin{array}{l}{ }^{*} \text { Corresponding Author: } \\
\text { Manjunatha M }\end{array}$ \\
\hline
\end{tabular}

\section{INTRODUCTION}

Concrete is the major constructional materials used for making steady and reliable infrastructure worldwide. Concrete is made up of cement, fine aggregates, coarse aggregates, water, and with or without chemical admixtures. Use of cement alone as a binder material produces large heat of hydration. While production of cement in manufacturing unit produces lots of $\mathrm{CO}_{2}$ emission and it is very harmful to the environment. Nowadays, the cement companies has taken initiative to reduce carbon dioxide emission by incorporating the industrial by products such as Ground Granulated Blast Furnace Slag (GGBS) and Fly Ash (FA) while production of cement in the manufacturing unit . Many researcher has carried lots of experiment by incorporating GGBS as alternative binder material for Ordinary Portland Cement in concrete to reduce $\mathrm{CO}_{2}$ emission and to overcome these problems. GGBS concrete is a type of concrete in which a part of cement is replaced with GGBS, which is an industrial waste. If concrete mix is replaced with ground granulated blast furnace slag as a partial replacement for Portland cement, it would provide environmental and economical benefits. GGBS has some pozzolanic properties it leads to increase the compressive strength of concrete (Suchitra Hirde, 2015). Concrete has been the major resources for providing stable and reliable infrastructure since the days of the Greek and roman civilization. Concrete is a mixture of cement, water, and aggregates, with or without admixtures. For construction of high rise building, commercial complex, and Apartments etc., the high strength concrete can be preferred over normal concrete. The high performance concrete cannot be achieved by using Ordinary Portland Cement. The strength can be improved to desired level by reducing water to cement ratio, by replacement of cement with some mineral admixture such as Silica fume, Ground Granulated Blast Furnace Slag, Metakaolin and Fly ash etc. with superplasticer (Adam, 2013).

From the experimental investigation, it is proved that, GGBS can be used as alternative material for the cement. The compressive, split tensile, flexural and Pull out strengths are increased as the percentage of GGBS increased up to $40 \%$ and above decrease (Adam Joe, 2013). The authors was concluded that, as percentage of GGBS increases the workability increases and the strength gets reduced. In order to increase the strength, cement is replaced by combination of GGBS and RHA. It was found that optimum replacement level of GGBS is $30 \%$ beyond the concrete strength decreases when compared to strength of plain cement concrete for 28 days (Roopa Thaira, 2016). It has been observed that the plain cement concrete prepared by OPC cement and 
Manjunatha and Jeevan

natural sand of M20 grade. The maximum compressive strength achieved is $32.59 \mathrm{Mpa}$ at $30 \%$ of GGBS replacement and those achieved for $20 \%, 40 \%$, and $50 \%$ of concrete is $31.11 \mathrm{Mpa}, 30.7 \mathrm{Mpa}$ and $27.74 \mathrm{Mpa}$ respectively as compare to $29.11 \mathrm{Mpa}$ of strength of plain cement concrete for 28 days (Vinayaka Awasare, 2014). In (Swaroop, 2013), the concrete with $20 \%$ GGBS is cured in sea water shows better response for durability criteria. The concrete with $20 \%$ Fly Ash is cured in H2SO4 solution curing has shown better response for durability criteria. It has been found the flexural strength is more at $10 \%$ and $20 \%$ GGBS in concrete with steel fiber when compared with normal concrete (Suchitha Hirde, 2015). It was observed there was only very small difference in compressive strength of specimens replaced with GGBS for cement and GBS for fine aggregate and was found to be $20 \%$ as that of control mix (Neelina, 2014). The behavioral resemblance of RCC beams with GGBS is same as the behavior of RCC beams without GGBS and there is increase in load carrying capacity of GGBS beams with age. The results suggest that $40 \%$ GGBS in concrete could be used for RC beams (Sangeetha, 2014). As the replacement level of cement by GGBS increases there is an increase in split tensile strength and flexural strength for M30 grade of concrete up to $50 \%$ replacement level, and beyond that level there is a
Sci. Technol. Arts Res. J., Oct-Dec 2015, 4(4): 148-155

decrease in split tensile and flexural strength (Anusha Suvarna, 2015).

The main aim of the research work is to study the fresh properties, early age strength properties, hardened properties and behaviour of concrete by partial replacement of cement with GGBS $(0-45 \%)$ for M35 and M40 grade concrete with super plasticizer. The objectives of the research work is to study the effect of GGBS on the workability of concrete, to study the behaviour of concrete when a portion of cement is partially replaced with GGBS, to compare the compressive strength of concrete containing GGBS with referral mix, to compare the percentage of strength gain for each mix proportion for 3 , 7 and 28 days and to obtain specific experimental data, visual observation and to understand fresh and hardened properties of concrete with and without GGBS.

\section{MATERIALS AND METHODS}

\section{Ordinary Portland Cement}

The Portland cement is most common type of cement in general use around the world because it is a basic ingredient of concrete. The Aditya Birla UltraTech Grade 53 Ordinary Portland Cement (OPC) is used in this experimental work.

Table 1: Physical Properties of UltraTech 53 Grade OPC

\begin{tabular}{|c|c|c|c|}
\hline No & Physical properties & $\begin{array}{c}\text { Test } \\
\text { Results }\end{array}$ & $\begin{array}{l}\text { Requirement of } \\
\text { IS:12269-1987 }\end{array}$ \\
\hline 1 & Fineness $\left(\mathrm{m}^{2} / \mathrm{Kg}\right)$ & 282 & $225(\min )$ \\
\hline 2 & Specific Gravity & 3.15 & - \\
\hline 3 & Standard Consistency (\%) & $29.0 \%$ & - \\
\hline 4 & $\begin{array}{l}\text { a) Initial setting time } \\
\text { b) Final setting time }\end{array}$ & $\begin{array}{l}175 \min \\
270 \min \end{array}$ & $\begin{array}{l}30 \min \\
600 \text { (Max) }\end{array}$ \\
\hline 5 & $\begin{array}{l}\text { Soundness } \\
\text { a) Le-chateleir Expansion. } \\
\text { b) Autoclave Expansion }\end{array}$ & $\begin{array}{l}0.7 \mathrm{~mm} \\
0.040 \%\end{array}$ & $\begin{array}{l}10(\text { Max }) \\
0.8(\text { Max })\end{array}$ \\
\hline 6 & $\begin{array}{l}\text { Compressive strength (Mpa) } \\
\text { a) } 72 \mathrm{hr}+/-1 \mathrm{hr} \text { ( 3days) } \\
\text { b) } 168+/-2 \mathrm{hr} \text { ( 7days) } \\
\text { c) } 672+/-4 \mathrm{hr} \text { ( 28days) }\end{array}$ & $\begin{array}{c}42.7 \\
54.2 \\
-\end{array}$ & $\begin{array}{l}27(\min ) \\
37(\min ) \\
53(\min )\end{array}$ \\
\hline 7 & $\begin{array}{l}\text { Performance Improver } \\
\text { a) Limestone } \\
\text { b) Fly ash } \\
\text { c) Granulated slag }\end{array}$ & $\begin{array}{l}5.0 \\
\text { NA } \\
\text { NA }\end{array}$ & $5.0(\max )$ \\
\hline
\end{tabular}

Table 2: Chemical Properties of UtraTech 53 Grade OPC

\begin{tabular}{llcc}
\hline No & Physical properties & $\begin{array}{c}\text { Test } \\
\text { Results }\end{array}$ & $\begin{array}{c}\text { Requirement of } \\
\text { IS:12269-1987 }\end{array}$ \\
\hline 1. & Insoluble Residue & 0.63 & $3.00($ Max $)$ \\
2. & Magnesia (\% by mass) & 1.1 & $6.00($ Max $)$ \\
3. & Sulphuric Anhydride (\% by mass) & 2.40 & $3.0(\operatorname{Max})$ \\
4. & Total loss on Ignition (\% by mass) & 2.10 & $4.00($ Max) \\
5. & Total Chloride (\% by mass) & 0.005 & $0.10($ Max) \\
\hline
\end{tabular}

\section{Coarse Aggregate}

The crushed stone aggregates of $20 \mathrm{~mm}$ and $10 \mathrm{~mm}$ size obtained from local quarry site were used for the research work. The specific gravity of the coarse aggregates were found to be 2.68. The water absorption values obtained for the aggregates is $0.5 \%$.

Table 3: Physical Properties of Coarse Aggregate as per IS: 2386-1963

\begin{tabular}{clc}
\hline No & Particulars & Test Results \\
\hline $\mathbf{1}$ & Bulk Density & $1350 \mathrm{Kg} / \mathrm{m}^{3}$ \\
$\mathbf{2}$ & Specific Gravity & 2.68 \\
$\mathbf{3}$ & Pre-Moisture Content & $0.5 \%$ \\
$\mathbf{4}$ & Shape & Angular \\
\hline
\end{tabular}




\section{Fine Aggregate}

The fine aggregate used for the research work was locally procured and conformed to grading zone III as per IS: $383-1970$.

Table 4: Physical Properties of Fine Aggregate as per IS: 2386-1963

\begin{tabular}{clc}
\hline No. & Particulars & Test Results \\
\hline 1. & Zone & III \\
2. & Bulk Density & $1400 \mathrm{Kg} / \mathrm{m}^{3}$ \\
3. & Specific Gravity & 2.65 \\
4. & Pre-Moisture Content & $1.5 \%$ \\
\hline
\end{tabular}

\section{Ground Granulated Blast Furnace}

For the use of GGBS as a mineral admixture in concrete, no Indian Code is available. The physical and chemical properties of GGBS are as follows.

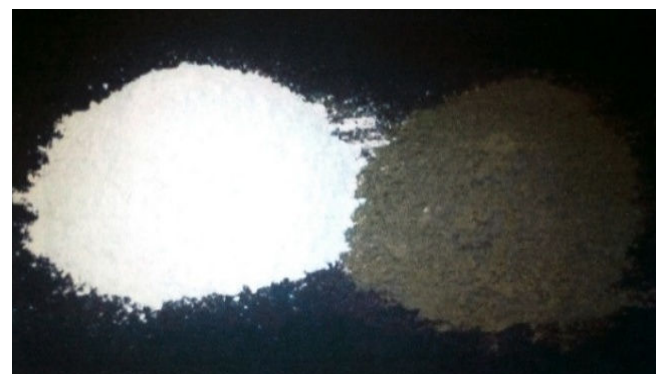

Figure 1: GGBS (Off white colour) and OPC
Table 5: Physical Properties of GGBS as per BS: 6699

\begin{tabular}{lll}
\hline No & Particulars & \multicolumn{1}{c}{ Test Results } \\
\hline $\mathbf{1}$ & Bulk Density & 1000 to $1100 \mathrm{Kg} / \mathrm{m}^{3}$ (Loose) \\
$\mathbf{2}$ & Specific Gravity & 1200 to $1300 \mathrm{Kg} / \mathrm{m}^{3}$ (Vibrated) \\
$\mathbf{3}$ & Fineness & 450 to $550 \mathrm{~m}^{2} / \mathrm{Kg}$ \\
$\mathbf{4}$ & Colour & Off white \\
$\mathbf{5}$ & Particle Shape & Powder form \\
\hline
\end{tabular}

Table 6: Chemical Properties of GGBS as per BS: 6699

\begin{tabular}{|c|l|c|}
\hline No & Particulars & Test Results \\
\hline $\mathbf{1}$ & Calcium oxide & $40 \%$ \\
\hline $\mathbf{2}$ & Silica & $35 \%$ \\
\hline $\mathbf{3}$ & Alumina & $13 \%$ \\
\hline $\mathbf{4}$ & Magnesia & $8 \%$ \\
\hline
\end{tabular}

Water

Portable water is generally considered satisfactorily for mixing concrete. Combining water with a cementitious material forms a cement paste by the process of hydration.

\section{Mix Design}

The concrete mix is designed based on IS: 10262 2009. The mix proportions for the M35 and M40 grade concrete as determined were 1:1.89:2.7 and 1:1.72:2.59 with water to cement ratio of 0.44 and 0.42 . The Rheobuild 1122 super plasticizer complies with IS: 91031999 were used and water content reduced up to $10 \%$.

Table 6: Mix Proportion for M35 Grade Concrete as per IS 10262:2009:

\begin{tabular}{|c|c|c|c|c|c|c|c|c|}
\hline $\begin{array}{c}\text { Mix } \\
\text { Designation }\end{array}$ & W/C & $\underset{\mathrm{Kg} / \mathrm{m}^{3}}{\mathrm{C}}$ & $\begin{array}{l}\text { GGBS } \\
\mathrm{kg} / \mathrm{m}^{3}\end{array}$ & $\begin{array}{c}\text { FA } \\
(10 \mathrm{~mm}) \\
\mathrm{Kg} / \mathrm{m}^{3}\end{array}$ & $\begin{array}{c}\text { CA } \\
(10 \mathrm{~mm}) \\
\mathrm{Kg} / \mathrm{m}^{3}\end{array}$ & $\begin{array}{c}\text { CA } \\
(20 \mathrm{~mm}) \\
\mathrm{Kg} / \mathrm{m}^{3}\end{array}$ & $\underset{\mathrm{Kg} / \mathrm{m}^{3}}{\mathrm{~W}}$ & $\begin{array}{c}\mathrm{SP} \\
\mathrm{Kg} / \mathrm{m}^{3}\end{array}$ \\
\hline NC (0\%) & 0.44 & 402 & 0 & 760 & 435 & 653 & 177 & 3.21 \\
\hline Mix-1(15\%) & 0.44 & 341.7 & 60.3 & 760 & 435 & 653 & 177 & 3.21 \\
\hline Mix-2(30\%) & 0.44 & 281.4 & 120.6 & 760 & 435 & 653 & 177 & 3.21 \\
\hline Mix-3(45\%) & 0.44 & 221.1 & 180.9 & 760 & 435 & 653 & 177 & 3.21 \\
\hline
\end{tabular}

Table 7: Mix Proportion for M40 Grade Concrete as per IS 10262:2009:

\begin{tabular}{|c|c|c|c|c|c|c|c|c|}
\hline $\begin{array}{c}\text { Mix } \\
\text { Designation }\end{array}$ & W/C & $\underset{\mathrm{Kg} / \mathrm{m}^{3}}{\mathrm{C}}$ & $\begin{array}{l}\text { GGBS } \\
\mathrm{kg} / \mathrm{m}^{3}\end{array}$ & $\begin{array}{c}\text { FA } \\
(10 \mathrm{~mm}) \\
\mathrm{Kg} / \mathrm{m}^{3}\end{array}$ & $\begin{array}{c}\mathrm{CA} \\
(10 \mathrm{~mm}) \\
\mathrm{Kg} / \mathrm{m}^{3}\end{array}$ & $\begin{array}{c}\text { CA } \\
(20 \mathrm{~mm}) \\
\mathrm{Kg} / \mathrm{m}^{3}\end{array}$ & $\underset{\mathrm{Kg} / \mathrm{m}^{3}}{\mathrm{~W}}$ & $\begin{array}{c}\mathrm{SP} \\
\mathrm{Kg} / \mathrm{m}^{3}\end{array}$ \\
\hline NC (0\%) & 0.42 & 420 & 0 & 726 & 435 & 653 & 177 & 3.36 \\
\hline Mix-1(15\%) & 0.42 & 357 & 63 & 726 & 435 & 653 & 177 & 3.36 \\
\hline Mix-2(30\%) & 0.42 & 294 & 126 & 726 & 435 & 653 & 177 & 3.36 \\
\hline Mix-3(45\%) & 0.42 & 231 & 189 & 726 & 435 & 653 & 177 & 3.36 \\
\hline
\end{tabular}

The calculated amount of concrete constituent materials were weighed and thoroughly mixed together in concrete mixer till the homogeneous wet mix was achieved. The cubes of $150 \mathrm{~mm}$ size were casted and compacted on vibrating table. Total 72 cubes were casted with various percentage of GGBS content, after the curing periods the concrete specimen tested for 3days, 7days and 28 days to study the fresh properties, early age properties and hardened properties.

\section{Compressive Strength Test}

The compressive strength test was carried out on compressive strength testing machine 200MT capacity. After curing periods, the concrete specimens were tested for 3days, 7days and 28days. The results of concrete specimen with various percentage of GGBS was compared with referral mix. 
Manjunatha and Jeevan

\section{RESULTS AND DISCUSSION}

The following graphs show the test results on the hardened concrete for 3,7 and 28 days. The compressive strength of all mixtures of M35 grade of concrete was obtained at the ages of 3,7 and 28 days, and the values are summarised in Table 8 and presented in Figure 2. The main aim of the research work is to utilize GGBS as a substitute material in the concrete production and cost
Sci. Technol. Arts Res. J., Oct-Dec 2015, 4(4): 148-155

can be reduced. The Portland cement concrete without GGBS shows better strength than GGBS concrete. The strength of Portland cement concrete at 3,7 and 28 days is $22.36,28$ and $43.47 \mathrm{~N} / \mathrm{mm}^{2}$. The concrete containing GGBS shows lower early age strength when compared with Portland cement concrete at 3 and 7 days. The GGBS concrete shows similar strength of Portland cement concrete at 28 days.

Table 8: Compressive Strength of M35 Grade

\begin{tabular}{ccccc}
\hline $\begin{array}{c}\text { Grade of } \\
\text { Concrete }\end{array}$ & $\begin{array}{c}\text { Replacement of } \\
\text { Cement by GGBS }\end{array}$ & \multicolumn{3}{c}{ Compressive strength N/mm } \\
& 3 days & 7 days & 28 days \\
\hline & $0 \%$ & 22.36 & 28 & 43.47 \\
M35 & $15 \%$ & 19.83 & 25.5 & 42.4 \\
& $30 \%$ & 18.5 & 21.42 & 41.69 \\
& $45 \%$ & 17.54 & 19.11 & 41.31 \\
\hline
\end{tabular}

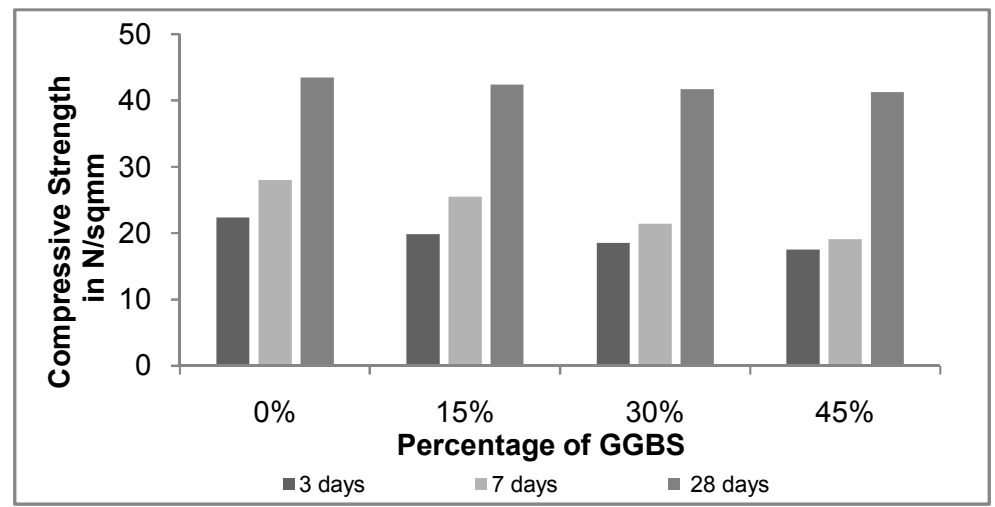

Figure 2: Variation of compressive strength of M35 grade concrete at different ages

The compressive strength of all mixtures of M40 grade concrete was obtained at the ages of 3 days, 7 days and 28days was summarised in Table 9 and Figure 3 . The GGBS is utilized as substitute material in the concrete production. The Portland cement concrete shows better strength than GGBS concrete. The strength of Portland cement concrete at 3,7 and 28 days is $25.63,33.8$ and
$51.27 \mathrm{~N} / \mathrm{mm}^{2}$. The concrete containing GGBS shows lower strength at early ages (3days and 7days) when compared with Portland cement concrete. The concrete with $15 \%$ GGBS shows compressive strength more than that of target mean strength of M40 grade concrete at 28days. Later stage GGBS concrete attains the 28days strength of Portland cement concrete.

Table 9: Compressive Strength of M40 Grade

\begin{tabular}{ccccc}
\hline $\begin{array}{c}\text { Grade of } \\
\text { Concrete }\end{array}$ & $\begin{array}{c}\text { Replacement of } \\
\text { Cement by GGBS }\end{array}$ & \multicolumn{3}{c}{ Compressive strength N $/ \mathbf{m m}^{\mathbf{2}}$} \\
& 3 days & 7 days & 28 days \\
\hline \multirow{4}{*}{ M35 } & $15 \%$ & 25.63 & 33.8 & 51.27 \\
& $30 \%$ & 22.29 & 32.44 & 51 \\
& $45 \%$ & 19.36 & 26.57 & 47.7 \\
\hline
\end{tabular}

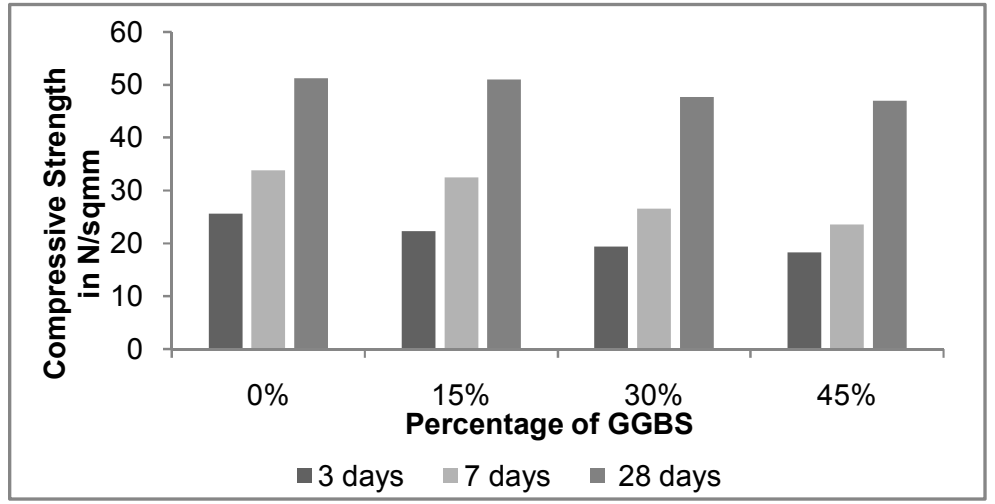

Figure 3: Variation of Compressive Strength of M40 Grade Concrete at different age 


\section{Manjunatha and Jeevan}

The percentage of strength gain at various days of M35 grade concrete at various percentage of GGBS was summarized in Table 10 and figure 4 . It has been observed that percentage of strength gain is $51.43,64.41$ and $100 \%$ for Portland cement concrete at 3days, 7 days and 28days. The concrete containing $15 \%$ GGBS, shows $46.67,60.14$ and $100 \%$ at 3days, 7 days and 28days. The
Sci. Technol. Arts Res. J., Oct-Dec 2015, 4(4): 148-155

concrete containing $30 \%$ GGBS, shows $40.58,51.38$ and $100 \%$ at 3,7 and 28 days. The concrete containing $45 \%$ GGBS, shows $38.8 \%, 46.25 \%$ and $100 \%$ at 3days, 7 days and 28 days. It is observed that the percentage gain in strength decreases as the percentage of GGBS increases at 3days and 7days. The GGBS concrete attains similar strength of Portland cement concrete at 28 days.

Table 10: Percentage of Strength gain in various days for M35 Grade of Concrete

\begin{tabular}{ccccc}
\hline Grade of & Replacement of & \multicolumn{3}{c}{ Compressive strength $\mathbf{N} / \mathbf{m m}^{\mathbf{2}}$} \\
\cline { 3 - 5 } Concrete & Cement by GGBS & 3days & 7days & 28days \\
\hline \multirow{3}{*}{ M35 } & $0 \%$ & 51.43 & 64.41 & 100 \\
& $15 \%$ & 46.67 & 60.14 & 100 \\
& $30 \%$ & 40.58 & 51.38 & 100 \\
& $45 \%$ & 38.8 & 46.25 & 100 \\
\hline
\end{tabular}

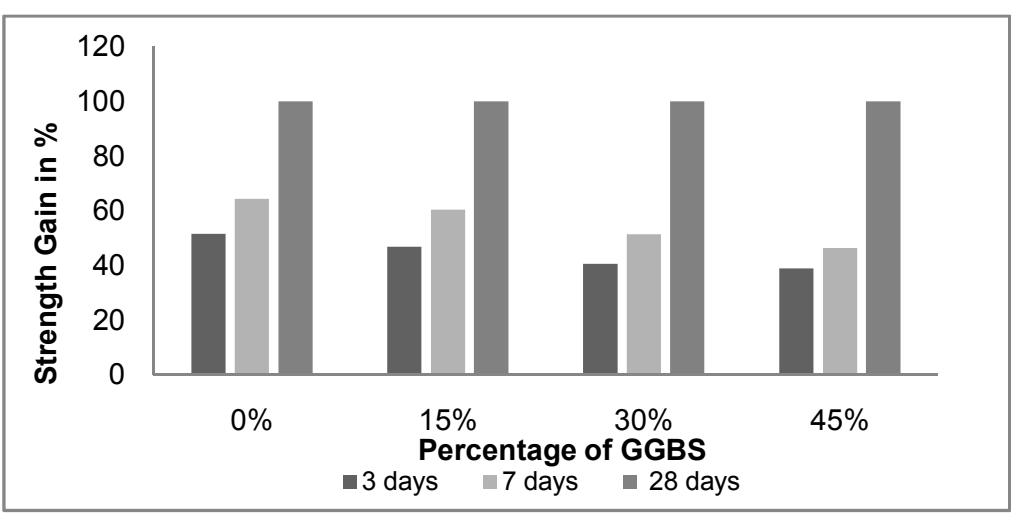

Figure 4: Percentage of Strength gained at various days of M35 Grade Concrete at various \% of GGBS

The percentage of strength gain at various days of M40 grade concrete at various percentage of GGBS was summarized in Table 11 and Figure 5 . It has been observed that percentage of strength gain is $51.43,64.41$ and $100 \%$ for Portland cement concrete at 3days, 7 days and 28days. The concrete containing $15 \%$ GGBS, shows $46.67,60.14$ and $100 \%$ at 3,7 and 28 days. The concrete containing $30 \%$ GGBS, shows $40.58,51.38$ and $100 \%$ at 3,7 and 28 days. The concrete containing $45 \%$ GGBS, shows $38.8,46.25$ and $100 \%$ at 3,7 and 28 days. It is observed that the percentage gain in strength decreases as the percentage of GGBS increases at 3days and 7days. The GGBS concrete attain similar strength of Portland cement concrete 28days.

Table 11: Percentage of Strength gain at various days for M40 Grade of Concrete

\begin{tabular}{ccccc}
\hline $\begin{array}{c}\text { Grade of } \\
\text { Concrete }\end{array}$ & $\begin{array}{c}\text { Replacement of } \\
\text { Cement by GGBS }\end{array}$ & \multicolumn{3}{c}{ Compressive strength $\mathbf{N} / \mathbf{m m}^{2}$} \\
3days & 7days & 28days \\
\hline \multirow{3}{*}{ M40 } & $0 \%$ & 50 & 65.92 & 100 \\
& $15 \%$ & 43.7 & 63.6 & 100 \\
& $30 \%$ & 40.6 & 55.7 & 100 \\
& $45 \%$ & 38.8 & 50.11 & 100 \\
\hline
\end{tabular}

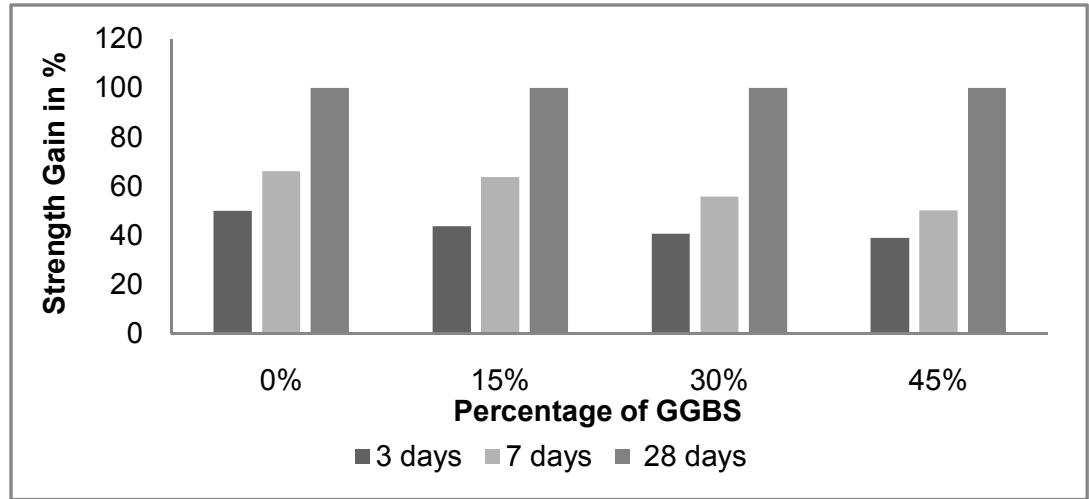

Figure 5: Percentage of Strength gained at various days of M40 Grade Concrete at various \% of GGBS 
Manjunatha and Jeevan

The workability of the concrete was measured through slump cone test apparatus at times ranging from immediate after mixing and after 30 minutes, the slump values was summarized in Table 12, 13 and Figure 6 . It is clearly observed that the slump of concrete increases as the GGBS content increases. The M40 grade of concrete
Sci. Technol. Arts Res. J., Oct-Dec 2015, 4(4): 148-155

shows better workability than the M35 grade. The dosage of super plasticizer can be reduced from $0.8 \%$ to $0.65 \%$ of cementitious content by increasing the GGBS content in M35 and M40 grade of concrete by maintaining desired value of slump. The cost of concrete production can be reduced by using GGBS as substitute material.

Table 12: Slump values for M35 Grade of Concrete

\begin{tabular}{ccccc}
\hline $\begin{array}{c}\text { Grade of } \\
\text { Concrete }\end{array}$ & $\begin{array}{c}\text { Replacement of } \\
\text { Cement by GGBS }\end{array}$ & $\begin{array}{c}\text { Slump in } \\
\text { 0 Min }\end{array}$ & $\begin{array}{c}\text { Slump in } \\
\text { 30 Min }\end{array}$ & $\begin{array}{c}\text { Dosage of chemical } \\
\text { admixture in \% }\end{array}$ \\
\hline & $0 \%$ & 120 & 65 & 0.8 \\
M35 & $15 \%$ & 125 & 70 & 0.75 \\
& $30 \%$ & 130 & 70 & 0.7 \\
& $45 \%$ & 135 & 75 & 0.65 \\
\hline
\end{tabular}

Table 13: Slump values for M40 Grade of Concrete

\begin{tabular}{ccccc}
\hline $\begin{array}{c}\text { Grade of } \\
\text { Concrete }\end{array}$ & $\begin{array}{c}\text { Replacement of } \\
\text { Cement by } \\
\text { GGBS }\end{array}$ & $\begin{array}{c}\text { Slump in } \\
\text { O Min }\end{array}$ & $\begin{array}{c}\text { Slump in } \\
\text { 30 Min }\end{array}$ & $\begin{array}{c}\text { Dosage of } \\
\text { chemical } \\
\text { admixture in \% }\end{array}$ \\
\hline \multirow{3}{*}{ M40 } & $0 \%$ & 120 & 65 & 0.8 \\
& $15 \%$ & 135 & 65 & 0.75 \\
& $30 \%$ & 140 & 75 & 0.7 \\
& $45 \%$ & 145 & 75 & 0.65 \\
\hline
\end{tabular}

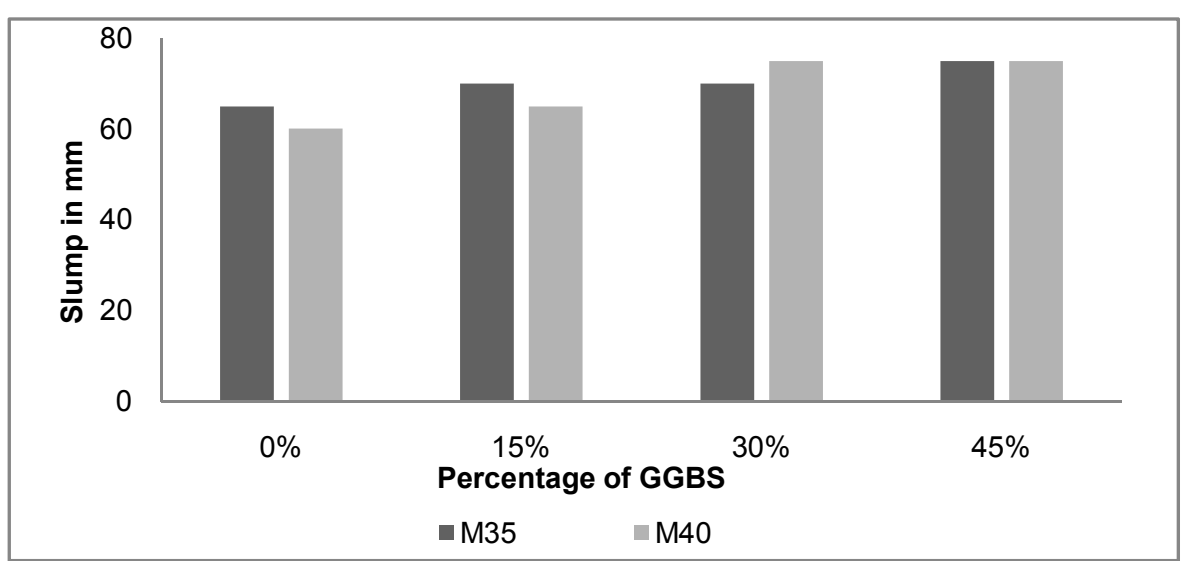

Figure 6: Slump values for M35 \& M40 Grade Concrete after 30min

Figure 7, shows the variation of compressive strength in 3days for various percentage of GGBS in concrete. It is observed that, the Portland cement concrete shows maximum strength at 3days when compared with GGBS concrete. The concrete containing GGBS shows lower strength at 3days when compared with Portland cement concrete. As the percentage of GGBS increases in concrete, the early age strength decreases. The concrete with GGBS content has better workability than Portland cement concrete.

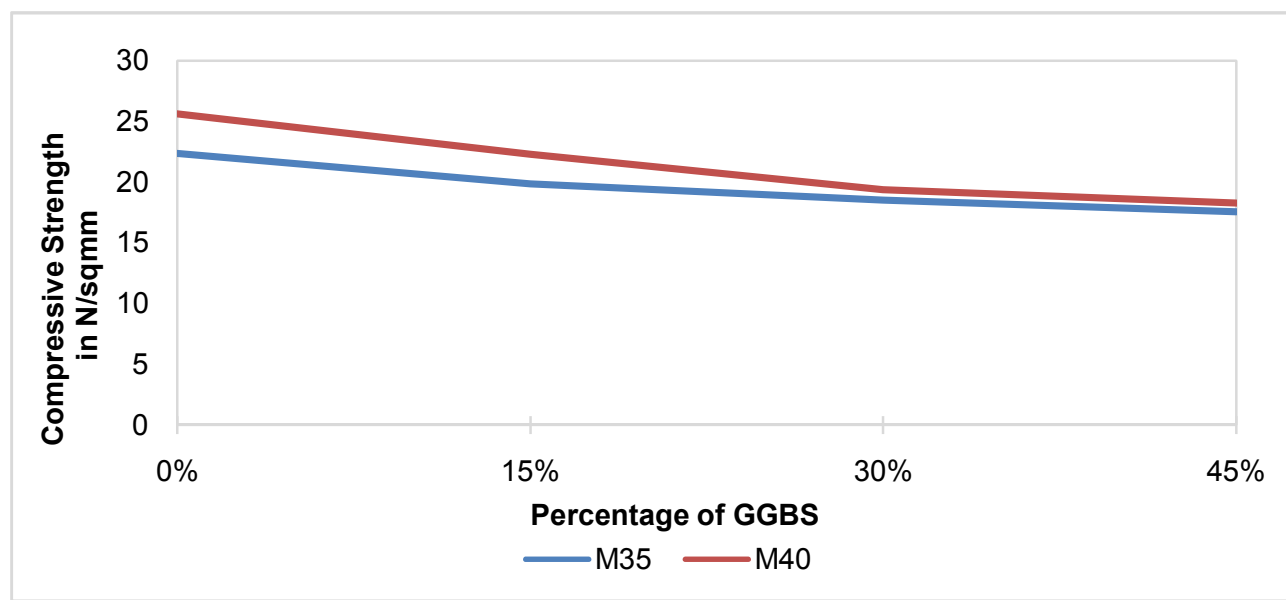

Figure 7: Variation of 3days Compressive Strength of M35 \& M40 Grade of Concrete at various \% of GGBS 


\section{Manjunatha and Jeevan}

Figure 8, shows the variation of compressive strength in 7days for various percentage of GGBS in concrete. It is observed that, the Portland cement concrete shows maximum strength at 7days when compared with GGBS concrete. The concrete containing GGBS shows lower strength at 7days when compared with Portland cement
Sci. Technol. Arts Res. J., Oct-Dec 2015, 4(4): 148-155

concrete. The compressive strength at 15\% GGBS content can be comparable with Portland cement concrete strength at 7days. As the percentage of GGBS increases in concrete, the early age strength decreases. The concrete with GGBS content has better workability than Portland cement concrete.

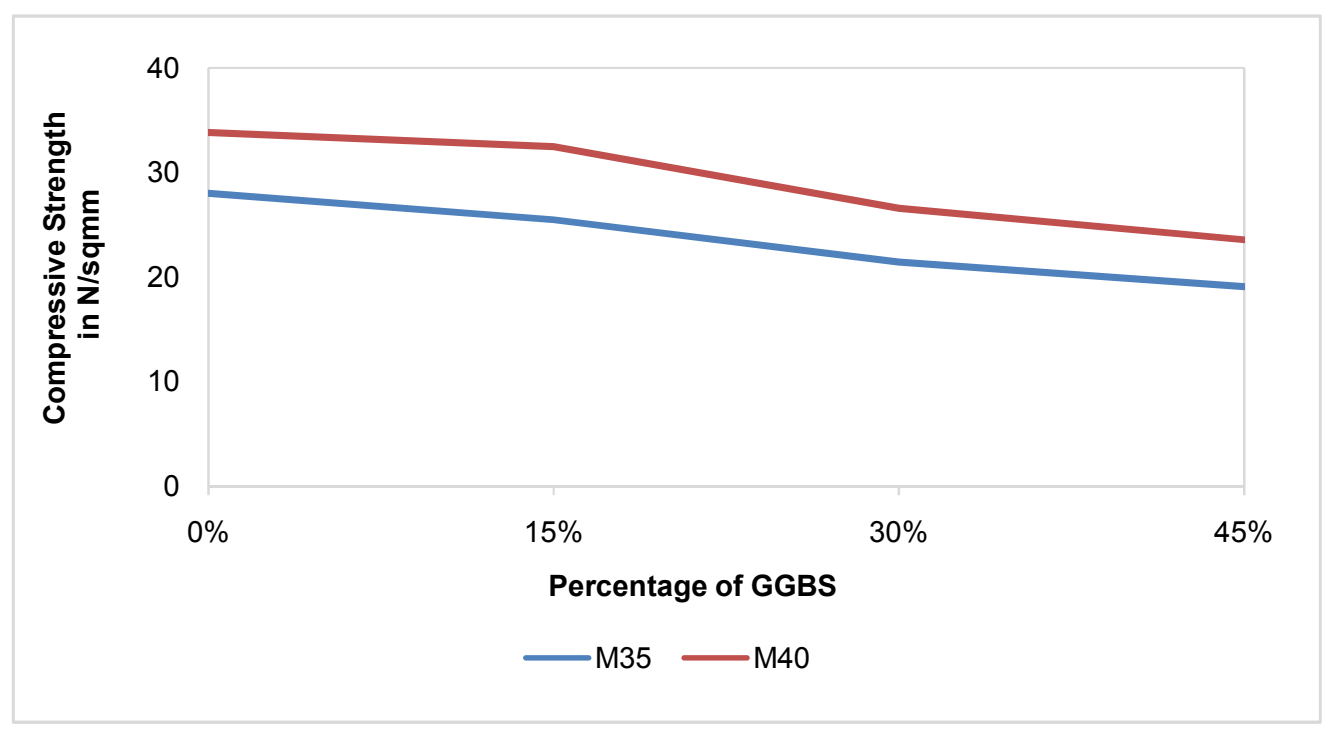

Figure 8: Variation of 7days Compressive Strength of M35 \& M40 Grade of Concrete at various \% of GGBS

Figure 9 , shows variation of 28 days compressive strength for various percentage of GGBS in M35 and M40 grade of concrete. It is observed that 28days compressive strength of GGBS concrete is comparable with Portland cement concrete. From the investigation, it can be concluded that $99 \%$ of compressive strength is achieved in GGBS concrete after 28days curing period.

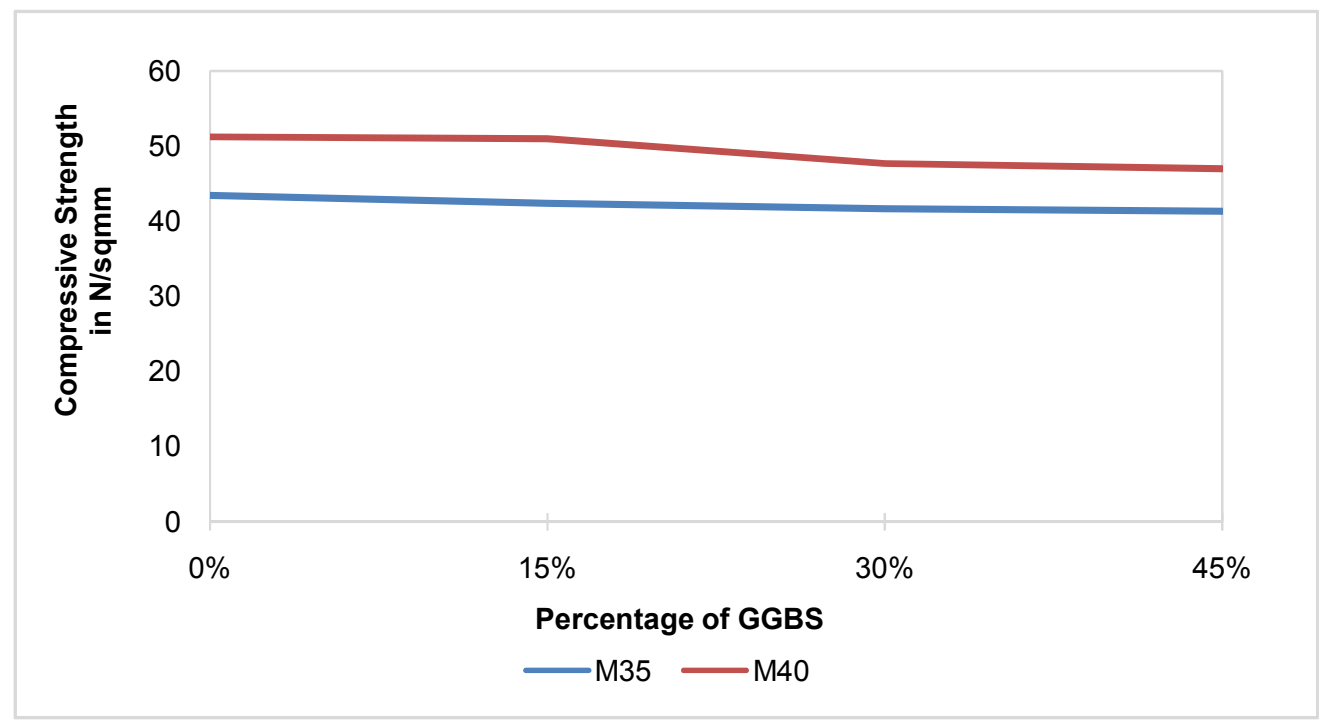

Figure 9: Variation of 28days Compressive Strength of M35 \& M40 Grade of Concrete at various \% of GGBS

\section{CONCLUSIONS}

From our result, it can be conclude that the degree of workability of concrete was improved by partial replacement of cement with GGBS up to $45 \%$ for both M35 and M40 grade concrete. It is observed that M40 grade concrete has better workability when compared with M35 grade. The GGBS is used as substitute for cement in concrete and it reduces the consumption of cement as well as cost of concrete production. From the investigation, we observed that the initial setting time of concrete is delayed due to increasing GGBS content in concrete. The concrete made with GGBS have lower strength at early ages, but gain strength more steadily than equivalent concrete made with Portland cement concrete which is having higher early age strength but does not rise rapidly on the later stages. The concrete containing $15 \%, 30 \%$ and $45 \%$ GGBS for both M35 and 


\section{Manjunatha and Jeevan}

M40 grade concrete achieve about $40 \%$ and $60 \%$ of their 28 days strength at 3 days and 7 days respectively. The performance of Portland cement concrete is considerably better than concrete with GGBS for 28days strength. The Portland cement concrete exhibiting a compressive strength slightly greater than GGBS concrete by about only $1 \mathrm{~N} / \mathrm{mm}^{2}$ to $3 \mathrm{~N} / \mathrm{mm}^{2}$ for 28 days strength. The Portland cement concrete achieves about $50 \%$ and $75 \%$ of its 28days strength at 3days and 7days respectively for M35 and M40 grade concrete.

\section{Acknowledgement}

The authors are grateful to Dr. Gopi Siddapa, Professor and Head, PESCE, Mandya, Karnataka, India, for providing laboratory facilities for carrying out research work. The cement and GGBS materials was sponsored by $\mathrm{M} / \mathrm{s}$ UltraTech Cement Limited, Bengaluru, Karnataka, India.

\section{Conflict of Interest}

Conflict of interest none declared.

\section{REFERENCES}

Adam Joe, M., Maria Rajesh, A. (2013). An Experimental Investigation on the Effect of GGBS and Steel Fibre in High Performance Concrete. International Journal of Computational Engineering Research 4(10): 56-59.

Roopa Thaira Thomas., Jebitta Fancy Rajaselvi P. (2016). An Experimental Investigation on the Effects of Concrete by
Sci. Technol. Arts Res. J., Oct-Dec 2015, 4(4): 148-155

Replacing Cement with GGBS and Rice Husk Ash with the Addition of Steel Fibres. International Journal of Science and Research 5(2): 2104-2106.

Vinayaka Awasare, M., Nagendra, V. (2014). Analysis of Strength Characteristics of GGBS Concrete. International Journal of Advanced Engineering Technology 5(2): 82-84.

Swaroop, A.H.L., Venkateswararao, K., Kondandaramarao, P. (2013). Durability Studies on Concrete with Fly Ash and GGBS. International Journal of Engineering Research \& Application 3(4): 285-289.

Suchita Hirde., Pravin Gorse, (2015). Effects of Addition of Ground Granulated Blast Furnace Slag on Mechanical Properties of Fibre Reinforced Concrete. International Journal of Current Engineering and Technology 5: 16771682.

Neelina M.S., Praveen Mathew. (2014). Effect of GGBS and GBS on the Properties of Self Compacting Concrete. International Journal of Innovative Research in Advanced Engineering 1(9): 211-216.

Sangeetha, S.P., Joanna, P.S. (2014). Flexural Behaviour of Reinforced Concrete Beams with Partial Replacement of GGBS. American Journal of Engineering Research 3(1): 119-127.

Anusha Suvarna, P.J. Salunke, N.G., Gore, T.N., Narkehde. (2015). Silica Fume and Ground Granulated Blast Furnace Slag as Cement Replacement in Fibre Reinforced Concrete. International Research Journal of Engineering and Technology 2(7): 438-443. 